\title{
RESEARCH OF THE INDUSTRIAL HERITAGE CATEGORY AND SPATIAL DENSITY DISTRIBUTION IN THE WALLOON REGION, BELGIUM, AND NORTHEAST CHINA
}

\author{
JIAZHEN ZHANG ${ }^{1}$, JEREMY CENCI ${ }^{1}$, VINCENT BECUE $^{1}$ \& SESIL KOUTRA $^{1,2}$ \\ ${ }^{1}$ Faculty of Architecture and Urban Planning, University of Mons, Belgium \\ ${ }^{2}$ Faculty of Engineering, Erasmus Mundus Joint Master SMACCs, University of Mons, Belgium
}

\begin{abstract}
Industrial heritage reflects the industrial civilization and industrial development process of the city in different periods, and its research and protection are conducive to the sustainable development of the city context. The Walloon Region in Belgium is one of the leading regions of industrial development in Western Europe, and Northeast China is the leading region of industrial development in China. The horizontal comparison of industrial heritage protection between the two regions is helpful to provide a reference for industrial heritage protection and urban regeneration of the two regions. It is found that the industrial heritages in both places are large in quantity and rich in types. The imbalance index of Walloon Region and Northeast China is 0.5001 and 0.6129 . The closer the number is to 1 , the more imbalance the distribution is. The distribution density of industrial heritages in Walloon Region is higher than that in Northeast China, and the types of industrial heritages in Northeast China are more than those in Walloon Region. The utilization rate of industrial heritage in the Walloon Region area is higher than that in Northeast China, and the main way of renewal is industrial tourism. The protection of industrial heritage in Northeast China is later than that in the Walloon Region, but it has the characteristics of sufficient stamina and rapid development. Strengthening the relationship between Europe and China in the protection of industrial heritage can provide reflection for the protection in Europe and experience for the protection in China.

Keywords: heritage category, industrial heritage conservation, industrial heritage, imbalance index, Northeast China, national industrial heritage, spatial density distribution, spatial distribution characteristics, Walloon Region.
\end{abstract}

\section{INTRODUCTION}

Along with the process of social development, an ocean of industrial facilities has been finished them historical duties. The research and conservation of them can contribute to the maintaining of historical memory and the sustainable development of urban construction [1]. Belgium, as one of the first countries, started the industrial revolution in Western Europe, has a great number of industrial heritage. As the leading region of the traditional industry, the industry has been developed in Walloon Region for more than 200 years. There is a huge number of industrial heritage and an affluent of experience in industrial heritage protection [2]. In East Asia, the traditional industrial bases in Northeast China are the cradle of China's industry. Like most of the traditional industrial region, with the deepening of reform and industrial update, the institutional and structural contradictions of the old industrial bases are increasingly apparent, and the further development is facing difficulties and problems [3]. The regeneration and aftermath of the industry in Northeast China is an important issue in the whole urban construction not only for China but also in East Asia.

On the one hand, the industry system in Walloon Region and Northeast China has similarities, for instance, both of them are the leading industrial region in their countries, both of them have a set of independent and complete industrial systems in their interior. Inside this system, most of the industrial facilities belong to the heavy industries that are facing elimination or transformation and upgrading. On the other hand, they have different cities, 
for instance, the industry in Walloon Region emerged earlier than in Northeast China. Therefore, put these two regions together to make a comparison, can not only burst out experience in industrial heritage protection but also offer an experience in urban regeneration in urban planning.

This paper is structured accordingly research the industrial category and spatial density distribution in Walloon Region and Northeast China: firstly, Section 2 introduce the data sources and research method, Sections 3 and 4 provide a presentation and analysis of the industrial heritage category and spatial density distribution in their individual region's; secondly, Sections 5 and 6 provide the main findings of the work the summary and discuss the perspectives for its continuity.

\section{DATA SOURCES AND RESEARCH METHOD}

\subsection{Data sources}

Thirty-six industrial heritages in the Walloon Region of Belgium based on the ERIH (European Route of Industrial Heritage) and 30 industrial heritages in Northeast China based on the List of the National Industrial Heritage of China (the first batch, the second batch, the third batch) were selected. Due to the analysis of spatial structure, the industrial heritages distributed in different regions are calculated according to different regions. The actual research objects are 38 industrial heritages in the Walloon Region of Belgium and 31 industrial heritages in Northeast China.

\subsection{Research method}

To provide strong support for scientific planning, classified protection, and effective utilization, this paper deeply analyzes the overall spatial distribution characteristics and an overall pattern of Walloon Region Belgium and Northeast China's industrial heritage applied through the spatial structure analysis that is one of the common methods in planning research. It can better analyze the spatial structure characteristics and spatial distribution law of the research object [4].

\subsection{Imbalance index}

The discrepancy of industrial heritage spatial structure presents discrepancy in different regional industrial heritage amount of distribution. The disequilibrium index is used to reflect the balanced distribution of industrial heritage in different regions, the equation is:

$$
S=\frac{\sum_{i=1}^{n} Y_{i}-50(n+1)}{100 n-50(n+1)}
$$

In this equation: $n$ presents the number of provinces and municipalities, in Walloon Region the $n=5$, in Northeast China the $n=3 ; Y_{i}$ presents the cumulative percentage of the $i$ th region in the total amount. Inside, $0 \leq S \leq 1$, if $S=0$, it presents industrial heritage is evenly distributed in all provinces and municipalities in Walloon Region or Northeast China; if $S=1$, it presents industrial heritage concentrating in one of the provinces or municipalities in Walloon Region or Northeast China; if the value of $S$ is more approaching 1, it presents the more imbalanced the distribution of industrial heritage is. 


\section{THE INDUSTRIAL HERITAGE CATEGORY AND SPATIAL DENSITY DISTRIBUTION IN WALLOON REGION}

Walloon Region is one of the three regions of Belgium which has $16,901 \mathrm{~km}^{2}$ with 3.644 million of the population [5]. As the leading region in the industry system in Belgium, there are a huge number of industrial facilities and heritages. Based on the European route of industrial heritage, in the Walloon region, it has thirty-eight industrial heritage landmarks. The main categories of them are Mining, Transport, and Manufacturing (Table 1). The spatial distribution of industrial heritage landmarks mainly concentrated in Liege district (Liege province) and Mons - Charleroi district (Hainaut province) (Fig. 1).

Table 1: Industrial heritage category and amount in Walloon Region.

\begin{tabular}{lcccccc}
\hline \multirow{2}{*}{ District distribution } & \multicolumn{7}{c}{ Industrial heritage category } & \\
\cline { 2 - 7 } & Transport & Mining & Manufacturing & Military & Others & Total \\
\hline Liege & 3 & 6 & 3 & 1 & 3 & 16 \\
Mons-Charleroi & 4 & 5 & 3 & - & - & 12 \\
Namur & 2 & - & 2 & 1 & - & 5 \\
\hline Arlon & 1 & 2 & 1 & - & - & 4 \\
Wavre & 1 & - & - & - & - & 1 \\
\hline Walloon Region & 11 & 13 & 9 & 2 & 3 & 38 \\
\hline
\end{tabular}

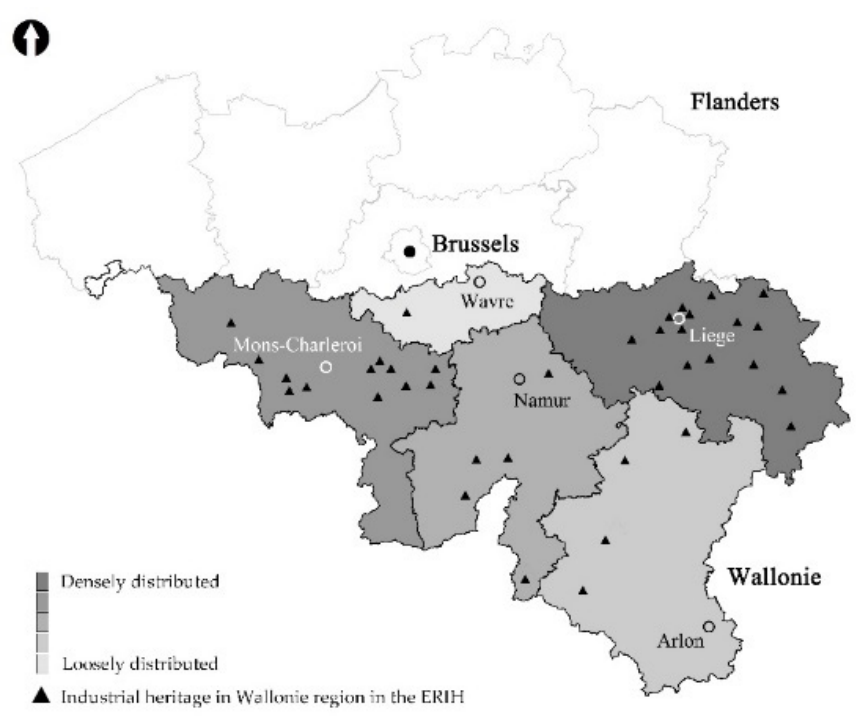

Figure 1: The industrial heritage landmarks spatial distribution in Walloon Region, Belgium.

According to the equation, after calculating and analyzing the data in the statistics on the distribution of industrial heritage in Walloon Region (Table 2), the imbalance index of industrial heritage in the Walloon Region is $S=0.5001$. This shows that the distribution of industrial heritage in the Walloon Region is imbalanced. Besides, it can also be found that the number of industrial heritage in districts of Liege and Mons-Charleroi alone is $73.69 \%$ of the total number of industrial heritages in Walloon Region. 
Table 2: Statistics on the distribution of industrial heritage in Walloon Region.

\begin{tabular}{clccc}
\hline No. & Administrative division & Amount & $\begin{array}{c}\text { Proportion } \\
(\%)\end{array}$ & $\begin{array}{c}\text { Cumulative proportion } \\
(\%)\end{array}$ \\
\hline 1 & Liege & 16 & 42.11 & 42.11 \\
2 & Mons-Charleroi & 12 & 31.58 & 73.69 \\
3 & Namur & 5 & 13.16 & 86.85 \\
4 & Arlon & 4 & 10.52 & 97.37 \\
5 & Wavre & 1 & 02.63 & 100.00 \\
\hline
\end{tabular}

From the angle of history, Liege district and Mons-Charleroi district are the most developed districts in Walloon Region in terms of economy and industrial construction since the beginning of the Industrial Revolution [6]. There are three main reasons. The first reason is geopolitics. Liege district borders Germany and Mons-Charleroi district borders France. The rapid development of the huge domestic markets of Germany and France has provided orders and markets for industrial products for Liege and Mons-Charleroi. The second reason is transportation, both Liege and Mons-Charleroi have well-developed railway and water transport facilities, which provides trade conditions for the expanding production capacity of the two places. To sum up, the industrial heritages created and left by these two districts are relatively large (Table 3) [7]-[9].

Table 3: Representative of industrial heritage in Walloon Region signed in UNESCO World Heritage site.

\begin{tabular}{lll}
\hline Name & Location & Category \\
The strépy-thieu boat lift & $\begin{array}{l}\text { Mons-Charleroi } \\
\text { district }\end{array}$
\end{tabular}




\section{THE INDUSTRIAL HERITAGE CATEGORY AND SPATIAL DENSITY DISTRIBUTION IN NORTHEAST CHINA}

Northeast China is a region of the northeast part of China, that including Liaoning, Heilongjiang, Jilin, three provinces. It has $787,300 \mathrm{~km}^{2}$ with 108 million of the population [10]. Like the Walloon Region in Belgium, Northeast China is the leading region in the industry system in history in China. The modern industry of China was born and raised here. Based on the List of the national industrial heritage of China (the first batch, the second batch, the third batch), in the Northeast China region, it has thirty-one industrial heritage landmarks. The main categories of them are Transport, Manufacturing, and Mining (Table 4). The spatial distribution of industrial heritage landmarks is mainly concentrated in Liaoning province (Fig. 2).

Table 4: Industrial heritage category and amount in Northeast China.

\begin{tabular}{|c|c|c|c|c|c|c|c|}
\hline \multirow{2}{*}{$\begin{array}{l}\text { District } \\
\text { distribution }\end{array}$} & \multicolumn{6}{|c|}{ Industrial heritage category } & \multirow[b]{2}{*}{ Total } \\
\hline & Transport & Mining & Manufacturing & Military & Energy & Others & \\
\hline Liaoning & 7 & 4 & 7 & 2 & 2 & - & 22 \\
\hline Heilongjiang & 2 & 1 & 1 & - & - & 2 & 6 \\
\hline Jilin & 1 & - & - & - & 1 & 1 & 3 \\
\hline $\begin{array}{l}\text { Northeast } \\
\text { China }\end{array}$ & 10 & 5 & 8 & 2 & 3 & 1 & 31 \\
\hline
\end{tabular}

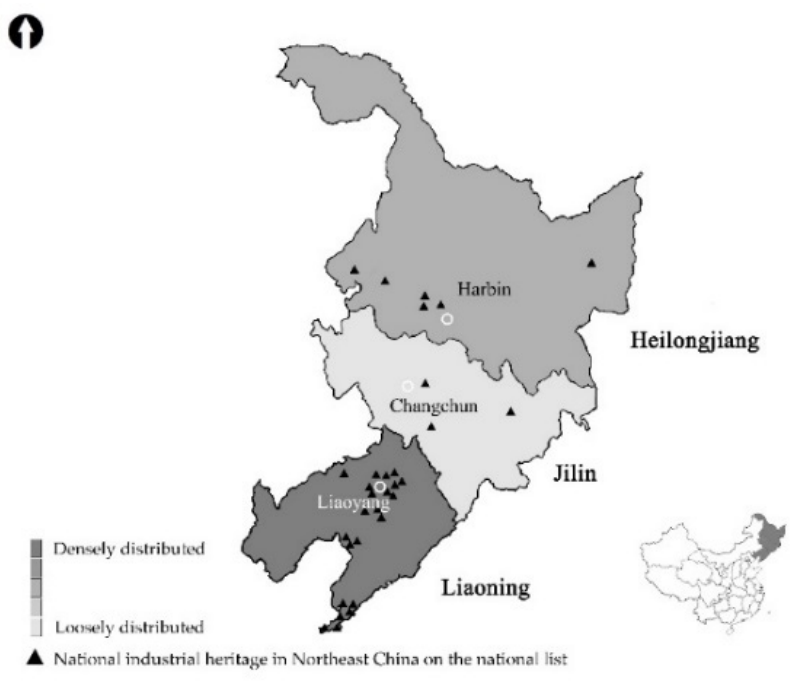

Figure 2: The industrial heritage landmarks spatial distribution in Northeast, China (PRC).

According to the equation, after calculating and analyzing the data in the statistics on the distribution of industrial heritage in Northeast China (Table 5), the imbalance index of industrial heritage in Northeast China is $S=0.6129$. This shows that the distribution of industrial heritage in Northeast China is extremely imbalanced. It can also be found that only the number of industrial heritage in Liaoning province alone is $70.97 \%$ of the total number of industrial heritages in Northeast China. 
Table 5: Statistics on the distribution of industrial heritage in Northeast China.

\begin{tabular}{clccc}
\hline No. & Administrative division & Amount & $\begin{array}{c}\text { Proportion } \\
(\%)\end{array}$ & $\begin{array}{c}\text { Cumulative } \\
\text { proportion }(\%)\end{array}$ \\
\hline 1 & Liaoning & 22 & 70.97 & 70.97 \\
2 & Heilongjiang & 6 & 19.35 & 90.32 \\
3 & Jilin & 3 & 09.68 & 100.00 \\
\hline
\end{tabular}

Due to its special historical background, at the end of the 19th century and the beginning of the 20th century, the textile, printing and dyeing, match and other light industry, machinery manufacturing, and even military industry rose in Liaoning province firstly.

Since the late Qing Dynasty in 1898, the germination of machine industry has been produced in Liaoning. After entering the period of China (ROC) in 1912, Liaoning's industrial development has entered a rapid period. Then Liaoning began in 1935 and was colonized by Japan for 14 years until the end of World War II [11]. After the founding of China (PRC), a national heavy industry base and a military-industrial base were first built here, giving birth to countless "firsts" in the industrial history of China (PRC).

At the end of the first 5-year plan, Liaoning's total industrial output value accounted for $16 \%$ of the country, ranking second in the country [12]. These special historical processes left rich industrial heritage not only for Liaoning province but also for the whole three northeast provinces of China (Table 6) [13].

Table 6: Representative of industrial heritage in Northeast China.

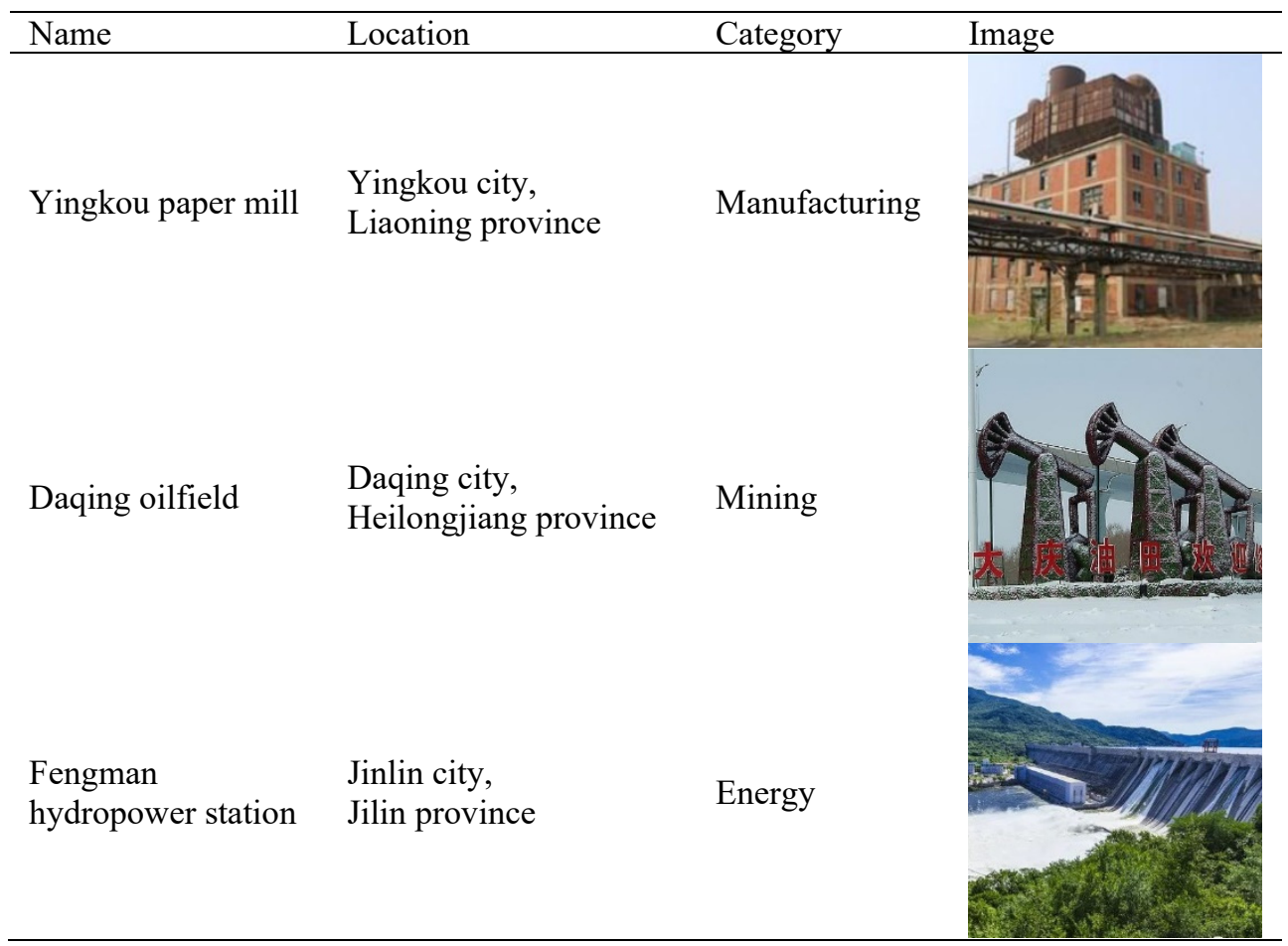




\section{RESULT}

The imbalance index of Walloon Region's 0.5001 is much lower than Northeast China's 0.6129 , it shows the distribution of industrial heritage in Northeast China is much higher imbalance than Walloon Region. The numbers of industrial heritage category in Walloon Region is less than in Northeast China, but the industrial heritage landmarks in Walloon Region is more than Northeast China. The main industrial heritage in Walloon Region is Mining, but it is Transport in Northeast China. The birth and development of the industry of these two regions mainly due to their geographical location and historical background. Therefore, the most density district distribution of their industrial heritage is located close to neighboring countries and the main categories are built by their historical stages of industrial development. In Walloon Region, Mons-Charleroi is close to France, Liege is close to Germany. In Northeast China, Heilongjiang is close to Russia, Liaoning is close to the Sea of Japan.

\section{DISCUSSION}

This research discusses the characteristics and causes of the spatial distribution of industrial heritage in Walloon Region, Belgium, and Northeast China from the regional scale, which is of great significance in scientific understanding and mastering the geographical spatial distribution of industrial heritage in Belgium and China and also has certain reference value for the protection and utilization of industrial heritage. The following aspects can be further studied in the future:

1. This research only discusses the current distribution characteristics of industrial heritage in Walloon Region and Northeast China from the perspective of space, and does not consider the internal differentiation of industrial heritage in China from the perspective of industrial categories. The influencing factors of distribution only consider the causes of the development of industrial heritage in the two regions from the perspective of history and geopolitics. The influence of industrial change, production division, and operation mode on the spatial distribution of industrial heritage is not considered.

2. This research only takes the industrial heritages of Walloon Region and Northeast China as the research objects. Although they are the leading industrial regions in their countries, however, this research did not put them into a broader regional scale to compared horizontally.

3. Industry is in a long-term changing process, social transformation and urbanization process will affect the industry. The post-industrialization degree of Walloon Region is higher than that of Northeast China. This study does not expand the concept of industrial heritage to a broader dimension to compare.

\section{CONCLUSION}

Both of the Walloon Region and Northeast China is the leading region in the industry in Belgium and China (PRC). However, there is no study to compare the two regions horizontally. This research fills this gap. In this research, the spatial distribution characteristics and influencing factors of 38 industrial heritages in Walloon Region of Belgium listed in the European Route of Industrial Heritage and 31 industrial heritages in Northeast China listed in the List of the National Industrial Heritage of China were analyzed in detail. From the scope of industrial heritage spatial density distribution, through geographic research method the imbalance index, after calculating and analyzing the data in the statistics on the distribution of industrial heritage. It found the imbalance index of industrial heritage in Walloon Region is much higher than that in Northeast China, the 
industrial heritages are mainly distributed in Liege and Mons-Charleroi districts, its distribution of industrial heritage category is less than Northeast China, only has 5 industrial heritage categories. Due to the special historical background, the industrial heritage of Northeast China has a strong colonial cultural color, the industrial heritages are mainly distributed in Liaoning province where is close to the sea of Japan. However, the same is that their main categories are concentrated in transportation and mining.

Through the longitudinal comparison of industrial heritage category and protection progress, the regeneration for industrial heritage in Walloon Region was started earlier than in Northeast China. Walloon region has entered the post-industrial era, with a large number of successful conservation cases and mature conservation experience. Northeast China is still exploring its path for the protection of industrial heritage. This can not only offer advanced experience in conservation from Walloon Region to Northeast China but also can present reflection for the protection of industrial heritage in Belgium.

The development of industry in Walloon Region was started earlier than in Northeast China, as well as the conservation of industrial heritage. However, the development speed has been slow down in the recent half-century gradually. On the contrary, the conservation of industrial heritage in Northeast China is getting attention incrementally. Landmark and social capital investment and social attention are increasing year by year. Keeping on eyes on industrial heritage conservation in Walloon Region and Northeast China will promote the two places to continuously stimulate endogenous power and radiate more vigor and vitality.

\section{ACKNOWLEDGEMENTS}

This research was funded and supported by the CoMod project (Compacité urbaine sous l' angle de la modélisation mathématique (théorie des graphes et des jeux)) and supported by the Faculty of Architecture and Urban Planning and the Faculty of Sciences, University of Mons.

\section{REFERENCES}

[1] Glumac, B. \& Decoville, A., Brownfield redevelopment challenges: A Luxembourg example. Journal of Urban Planning and Development, p. 146, 05020001-1-9, 2020.

[2] Zhang, J., The overview of the conservation and renewal of the industrial Belgian heritage as a vector for cultural regeneration. Information, 12, p. 27, 2021.

[3] Gaofeng, W., The research status of industrial heritage in China. Industrial Architecture, 43(1), 2013 (in Chinese).

[4] Du Plessis, D.J., The evolving spatial structure of South African cities: A reflection on the influence of spatial planning policies. International Planning Studies, 20(1-2), p. 87, 2015.

[5] Statbel.fgov.be. https://statbel.fgov.be/nl/themas/bevolking/structuur-van-debevolking. Accessed on: 01 Feb. 2021.

[6] Zhang, J., The overview of the conservation and renewal of the industrial Belgian heritage as a vector for cultural regeneration. Information, 12, 27, 2021.

[7] The official website of the strépy-thieu boat lift. https://www.canalducentre.be/ en/visits/the-boat-lift-of-strepy-thieu/. Accessed on: 26 Apr. 2021.

[8] The official website of the le bois du cazier world heritage site. https://www.leboisducazier.be/. Accessed on: 26 Apr. 2021.

[9] The official website of the Blegny mine world heritage site. https://www.blegnymine.be/. Accessed on: 26 Apr. 2021.

[10] Yin, L., Study on the interprovincial population migration and its influencing factors in Northeast China. Jilin University, 2015 (in Chinese). 
[11] Li, M., Advantages, problems and countermeasures of industrial heritage tourism development in Liaoning Province. Journal of Capital University of Economics and Trade, 16(4), pp. 65-68, 2014 (in Chinese).

[12] Guo, M., Challenges and countermeasures of developing open economy in the northeast old industrial base - Taking Liaoning old industrial base as an example. Economic Review, 1, pp. 65-69, 2016 (in Chinese).

[13] National industrial heritage list released, the official website of the ministry of industry and information technology website. https://www.miit.gov.cn/zwgk/wjgs/art/2020/ art_dde0deaecfaf46b395e1de1ee401058c.html. Accessed on: 26 Apr. 2021 (in Chinese). 